\title{
An optimum location of on-grid bifacial based photovoltaic system in Iraq
}

\author{
Amina Mahmoud Shakir, Siba Monther Yousif, Anas Lateef Mahmood \\ Department of Electronic and Communications Engineering, College of Engineering, Al-Nahrain University, Baghdad, Iraq
}

\begin{abstract}
Article Info
Article history:

Received Apr 1, 2021

Revised Jul 15, 2021

Accepted Jul 30, 2021

\section{Keywords:}

Bifacial PV panel

On grid system

Photovoltaic system

PVsyst software

ABSTRACT

Bifacial photovoltaic (PV) module can gain $30 \%$ more energy compared to monofacial if a suitable location were chosen. Iraq (a Middle East country) has a variable irradiation level according to its geographic coordinates, thus, the performance of PV systems differs. This paper an array (17 series, 13 parallel) was chosen to produce $100 \mathrm{kWp}$ for an on-grid PV system. It investigates the PV system in three cities in Iraq (Mosul, Baghdad, and Basrah). Effect of albedo factor, high and pitch of the bifacial module on energy yield have been studied using PVsyst (software). It has been found that the effect is less for a pitch greater than $6 \mathrm{~m}$. The energy gained from bifacial and monofacial PV system module in these cities shows that Mosul is the most suitable for installing both PV systems followed by Baghdad and lastly Basrah. However, in Basrah, the bifacial gain is $12 \%$ higher in the energy than monofacial as irradiation there is higher than the other locations, especially for elevation above $1.5 \mathrm{~m}$. Moreover, the cost of bifacial array is $7.23 \%$ higher than monofacial, but this additional cost is acceptable since the bifacial gain is about $11.3 \%$ higher energy compared to the monofacial.
\end{abstract}

This is an open access article under the CC BY-SA license.

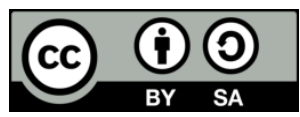

\section{Corresponding Author:}

Amina Mahmoud Shakir

Department of Electronic and Communications Engineering, College of Engineering

Al-Nahrain University

Jadriyah, Baghdad, Iraq

Email: aminaalkafajiam@gmail.com

\section{NOMENCLATURE}

$\begin{array}{ll}\text { Abbreviations } \\ \text { HJT } & \text { Heterojunction technology solar cells } \\ \text { PERC } & \text { Passivated emitter and rear solar cells } \\ \text { PERT } & \begin{array}{l}\text { Passivated emitter and rear totally diffused } \\ \text { solar cells }\end{array} \\ \text { PV } & \text { Photovoltaic } \\ \text { RT } & \text { Ray Tracing } \\ \text { STC } & \text { Standard test conditions }\left(1000 \mathrm{~W} / \mathrm{m}^{2}, 25^{\circ} \mathrm{C}\right) \\ \text { Symbols } & \\ \text { A1, A2 } & \text { Random surfaces } \\ \text { BHI } & \text { Direct horizontal beam irradiation }\left(\mathrm{W} / \mathrm{m}^{2}\right) \\ \text { dA1, dA2 } & \text { Differential areas of surfaces A1 andA2 } \\ \text { DHI } & \text { Diffused horizontal irradiation }\left(\mathrm{W} / \mathrm{m}^{2}\right) \\ \text { E } & \text { Module elevation from ground } \\ F_{A 1 \rightarrow A 2} & \text { View factor for radiation leaving surface A1 } \\ \text { GHI } & \text { and strikes surface A2 }\end{array}$

Journal homepage: http://ijece.iaescore.com

$\begin{array}{ll}\text { Symbols cont. } \\ \mathrm{H} & \text { Module height } \\ \mathrm{I}_{\mathrm{BN}} & \text { Normal beam irradiation }\left(\mathrm{W} / \mathrm{m}^{2}\right) \\ \mathrm{I}_{\text {FDiff }} & \text { Front side diffused irradiation }\left(\mathrm{W} / \mathrm{m}^{2}\right) \\ \mathrm{I}_{\text {FDir }} & \text { Front side direct irradiation }\left(\mathrm{W} / \mathrm{m}^{2}\right) \\ \mathrm{I}_{\mathrm{FGref}} & \text { Front side ground reflected irradiation }\left(\mathrm{W} / \mathrm{m}^{2}\right) \\ \mathrm{I}_{\text {Front }} & \text { Front total incident irradiation }\left(\mathrm{W} / \mathrm{m}^{2}\right) \\ \mathrm{I}_{\mathrm{RDiff}} & \text { Rare side diffused irradiation }\left(\mathrm{W} / \mathrm{m}^{2}\right) \\ \mathrm{I}_{\mathrm{RDir}} & \text { Rare side direct irradiation }\left(\mathrm{W} / \mathrm{m}^{2}\right) \\ \mathrm{I}_{\mathrm{RGref}} & \text { Rare side ground reflected irradiation }\left(\mathrm{W} / \mathrm{m}^{2}\right) \\ \mathrm{I}_{\text {Total }} & \text { Total bifacial PV irradiation }\left(\mathrm{W} / \mathrm{m}^{2}\right) \\ \mathrm{R}_{\mathrm{ns}} & \text { Non-shading surface } \\ \mathrm{R}_{\mathrm{s}} & \text { Shading surface } \\ \mathrm{S} & \text { Distance between differential areas } \\ \alpha & \text { Albedo factor } \\ \theta 1, \theta 2 & \text { Angle between the normal vectors of the surfaces } \\ & \text { A1 and A2 and the differential area dA1 and dA2 }\end{array}$




\section{INTRODUCTION}

With the world's growing demand for clean and renewable energy, studies have been focusing on ways to maximize the performance of photovoltaic (PV) systems. The geographical location of the photovoltaic system is a crucial issue which must be decided precisely. Irradiation and temperature are the main factors affected by the geographical location and therefore they effect on the PV system yield.

Bifacial panel is a new technology which collects the irradiation that reaches to the front side of the panel as well as the reflected irradiation from the ground to the back side of the panel. Therefore, the photovoltaic system will produce a larger amount of energy than the conventional one. It can generate more than $50 \%$ energy in comparison with the monofacial module depending on the PV technology, location, and installation techniques [1]. Many studies show that the increase in the instantaneous output power may be 40-70\% under cloudy conditions and $15-35 \%$ in sunny conditions [2]. Some studies focus on the effective parameters that alter the output power of the bifacial module which are represented by tilt angle, elevation from the ground, and the pitch between modules [3]-[5]. Others have studied the effect of the surrounding medium albedo factor on the output power of the module [6], [7], whereas the impact of temperature on the efficiency of the PV modules are considered in [8] and [9].

Few researchers analyze the importance of the PV system location which depends on bifacial PV array in Iraq. They studied the effect of tilt angle, irradiation, and temperature change on the back to back monofacial panel at Baghdad city [10], while a stand-alone monofacial PV system with and without shading at performance is analyzed in [11]-[13]. Other researchers have studied the performance of the photovoltaic monofacial in Al-Najaf [14].

As on-grid PV system location is substantial, especially for interconnected power system. This study focuses on the on-grid PV system performance for three different locations in Iraq in order to decide the optimum location to obtain the maximum yearly energy production from the PV system. As a comparison between monofacial and bifacial array, the two PV array configurations are considered, and the effect of the different parameters on their performance of the PV system is examined.

\section{BIFACIAL PV SYSTEM}

The conventional monofacial PVs front side surface is covered with glass lamination in order to allow irradiation to penetrate through it, while an opaque metallic sheet covers the whole rear side surface of the PV. The construction of the front side of bifacial PV panel is similar to that of monofacial while the rear side is covered with glass. This will allow more irradiation to penetrate through the PV panel from the rare side and hence the yield of energy generated increases. Figure 1 illustrates the construction layers for the two types of PV panels.

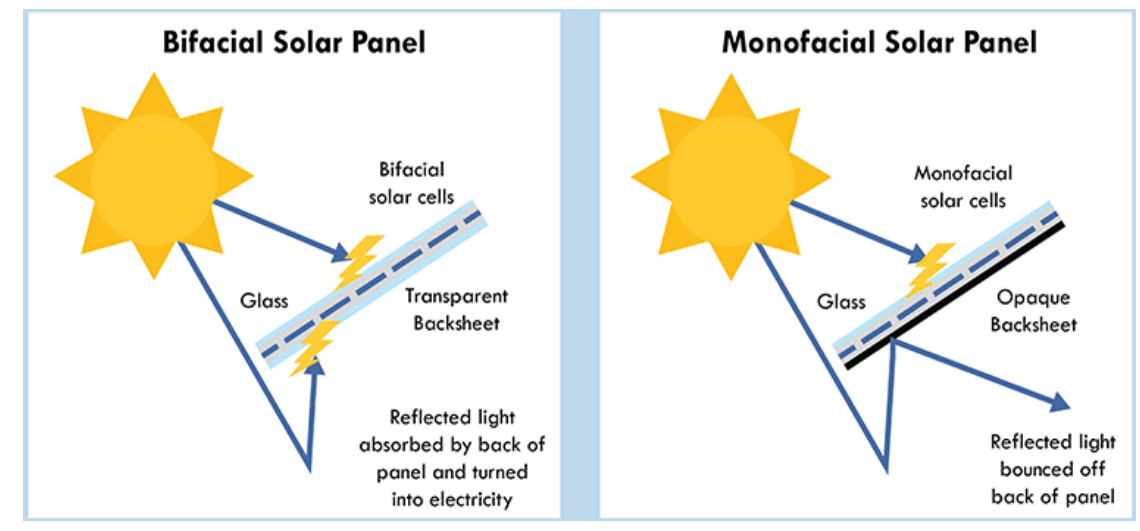

Figure 1. PV bifacial and monofacial PV types construction

Even though bifacial PV panel receives light from both sides, the efficiency of the rear side is lower than that of the frontside. The bifacial PV panel performance is essentially dependent on the bifacially factor of the panel. The bifacially factor is calculated as the ratio of the rare side power to the frontside power at standard test conditions (STC) $\left(1000 \mathrm{~W} / \mathrm{m}^{2}\right.$ and $\left.25^{\circ} \mathrm{C}\right)[15]$.

$$
\text { Bifaciality factor }=\text { Rearside Power at STC/Frontside Power at STC }
$$


Several bifacial PV techniques have been used to increase the effectiveness of PV cells. The most modern common techniques are: passivated emitter and rear (PERC) solar cells, passivated emitter and rear totally diffused (PERT) solar cells, and heterojunction technology (HJT). Each of these technologies has its cell structure, faciality factor, efficiency, and manufacturing cost [16].

\subsection{Factors affecting bifacial PV module gain}

The main factors that effects the bifacial gain are the geographical location and PV module configuration. Since the bifacial PV panel is based on the same principles as the conventional PV panel, geographical location is a significant factor that determines its performance. It is mostly affected by temperature, irradiation and wind speed. The PV panel temperature mainly depends on the environmental conditions such as sky temperature, wind speed, module construction, technology-specific (monofacial or bifacial cells) and thermal coefficient of maximum power. Temperature dependence plays an important role in assessing site-specific energy gain outcomes around the world [17]. Therefore, proper location for installing the PV system should be carefully chosen [18].

The PV module configuration affects its gain. As the bifacial PV panel receives irradiation from front and rare side, it greatly depends on the albedo factor that is defined as, "the ratio of surface reflected to incident irradiation" [19]. Albedo is a unit less factor that is depend on ground surface properties and it varies between 0 and 1. Table 1 lists the albedo factor for different ground surface conditions [20].

The energy yield of PV panels has been mostly affected by the amount of solar irradiation which incidents on photovoltaic panels [21]. Moreover, it can be increased by optimizing the design parameters: azimuth angle, tilt angle, and elevation. Figure 2(a) illustrates the schematic of a bifacial solar module where $\mathrm{E}$ and $\mathrm{H}$ are the solar module elevation and height, while Figure 2(b) shows the bifacial module design parameters. Azimuth angle varies throughout the day since it represents the angle of the sun's rays measured in the horizontal plan of full south (true south) of the northern hemisphere or full north for the southern hemisphere [22]. While tilt angle is defined as the angle between the PV panels and the horizontal plane and it has to be chosen correctly in order to increase the amount of incident irradiation on the panel. It depends on many parameters, such as the location of the plant, the size of the system and time of the year. Elevation which is the clearance of the module above ground is also an effective parameter to gain more energy from PV panel. In general, bifacial gain increases with elevation up to $1 \mathrm{~m}$, and its effect is eliminated as it increases. Furthermore, row spacing (pitch) which is the distance between the front of a PV array to the behind array is an important factor that affects the gain of the bifacial module. As the row spacing increases, energy production increases [23].

\begin{tabular}{cc} 
Table 1 Approximate albedo factor for different surfaces [20] \\
\cline { 2 - 3 } Surface & Albedo \\
\cline { 2 - 3 } Corrugated roof & $0.1-0.15$ \\
Colored paint & $0.15-0.35$ \\
Trees & $0.15-0.18$ \\
Asphalt & $0.05-0.2$ \\
Concrete & $0.25-0.7$ \\
Grass & $0.25-0.3$ \\
Ice & $0.3-0.5$ \\
Red/Brown roof tiles & $0.1-0.35$ \\
Brick/Stone & $0.2-0.4$ \\
Oceans & $0.05-0.1$ \\
Old snow & $0.65-0.81$ \\
White paint & $0.5-0.9$ \\
Fresh Snow & $0.81-0.88$ \\
\hline
\end{tabular}

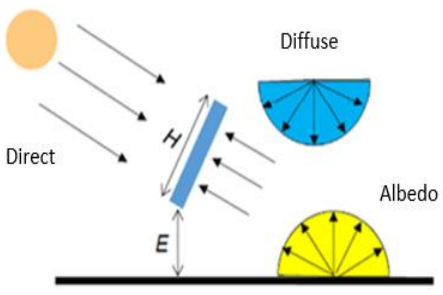

(a)

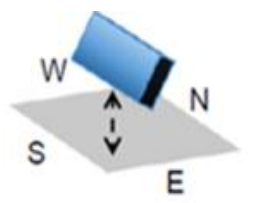

Elevation

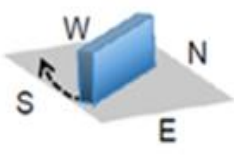

Azimuth Angle

(b)

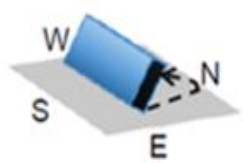

Tilt Angle

Figure 2. Design parameters: (a) schematic of a bifacial solar module where $\mathrm{E}$ and $\mathrm{H}$ are the solar module elevation and height; (b) design parameters [3] 


\subsection{Bifacial PV irradiance modelling}

An irradiance model is required to predict incoming irradiance at the front and rear side of the solar module. Bifacial PV modeling is much more complex than monofacial PV modeling due to the need for estimation of the module rear side irradiation, which is dependent on several factors. The total bifacial PV irradiation ( $\left.I_{\text {Total }}\right)$ can be determined as in (2) [24],

$$
I_{\text {Total }}=I_{\text {Front }}+\left(I_{\text {Rear }}\right) \times(\text { Bif aciality Factor })
$$

where $I_{\text {Front }}$ is the total front side incident irradiation and $I_{\text {Rear }}$ is the rear side irradiation.

Conceptually, as shown in Figure 3, the total irradiance at the front and rear of module is the result of combining [25]:

a) Sky diffuses irradiance. The visible sky is dependent on the tilt angle and azimuth of the module and is limited by other neighbouring structures.

b) Irradiance reflected to the ground that may vary across the surfaces behind the module due to the albedo and the incident of irradiance to the ground surfaces.

c) Radiance reflected by the structure from nearby objects, such as the front of the PV modules in an adjacent row.

d) The direct irradiance to the rear surface, e.g., when the elevation of the sun is low and the azimuth of the sun is northeast or northwest of a southerly network.

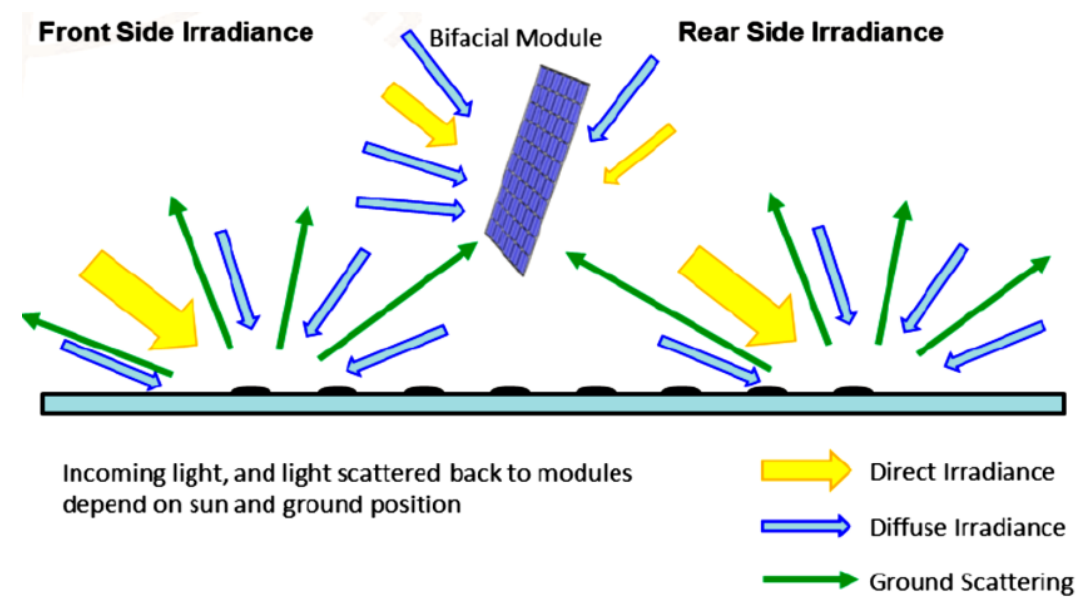

Figure 3. Irradiance on bifacial module [28]

Different rear sides of the module may have different irradiation values. The reason behind that is the irradiance which is generally not uniform over the entire area of a PV module. Therefore, we need to use an average value to represent irradiance on each side. As these irradiances are evaluated, the overall irradiance can be estimated. The total front side irradiance $\left(I_{\text {Front }}\right)$ that reaches the PV module can be evaluated using (3).

$$
I_{\text {Front }}=I_{\text {FDir }}+I_{\text {FGref }}+I_{\text {FDiff }}
$$

Where $\left(I_{F D i r}\right),\left(I_{F G r e f}\right)$ and $\left(I_{F D i f f}\right)$ are the direct irradiance, ground reflected irradiance and diffused irradiance, respectively. IFDir can be computed using the position of the sun and normal beam irradiation $I_{B N}, I_{F G r e f}$ is determined using the isotropic model [26] and $I_{F D i f f}$ is calculated using Perez model [27].

The direct $\left(I_{R D i r}\right)$ and diffuse $\left(I_{R D i f f}\right)$ irradiances that reach the module rear side can be determined using the same methods as the front side. The results of isotropic model ground reflected irradiance (IRGref) for the rear side is inaccurate, therefore, a more complicated calculation is necessary [29]. Currently, the most significant optical models used to quantify irradiance at the rear of a bifacial solar panel are the view factor (VF) and ray tracing (RT). The hourly VF and RT approaches can model the cumulative long-term irradiance received by decisive solar cells with a very high accuracy ranging from $0.5 \%$ to $2 \%$ [30]. This present work is based on the view factor model. 
The view factor $F_{A 1 \rightarrow A 2}$ is a geometric quantity which gives the fraction of the radiation leaving a random surface A1 and strikes the surface A2 directly. It is depending upon the orientation of the surfaces to each other and the distance between them. In this case, the surface A1 is the ground whereas A2 is the rear surface of the module. The view factor assumes that A1 and A2 are ideal diffuse reflectors, and they are independent of temperature and other surface properties. The view factor $F_{A 1 \rightarrow A 2}$ can be calculated as the integral of the portions of radiation leaving the differential areas $d A 1$ which reach the differential areas $d A 2$ and it is illustrated in Figure 4 [31]:

$$
F_{A 1 \rightarrow A 2}=\frac{1}{A 1} \int_{A 1} \int_{A 2} \frac{\cos \theta_{1} \cos \theta_{2}}{\pi S^{2}} d A 1 d A 2
$$

where $S$ is the distance between the differential areas $d A 1$ and $d A 2$. The angles between the normal vectors of the surfaces and the line that connects $d A 1$ and $d A 2$ are $\theta_{1}$ and $\theta_{2}$, respectively. The ground beneath the module A1 is then divided into two parts, the area inside and the area outside the shadow, $R s$ and $R n s$, respectively, as shown in Figure 4.

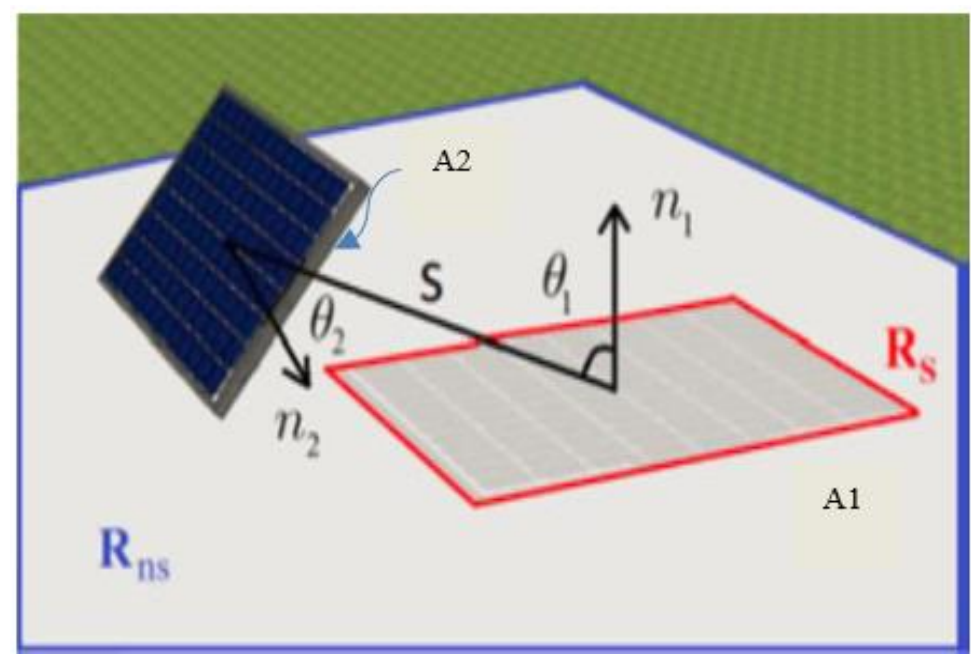

Figure 4. Visual depiction of parameters required for VF calculation

As the direct horizontal irradiance (beam) BHI is blocked by the module, by casting a shadow on the ground, only the diffuse horizontal irradiance DHI is reflected from the shadow area. However, from the region outside the shadow, both $B H I$ and $D H I$ are reflected. The rear reflected irradiation $I_{R G r e f}$ is the sum of the reflected irradiation from the shading and non-shading area $R s$ and $R n s$, respectively. Therefore, $I_{R G r e f}$ can be given by:

$$
I_{R G r e f}=\alpha G H I F_{R n s \rightarrow A 2}+\alpha D H I F_{R s \rightarrow A 2}
$$

where $\alpha$ is the albedo factor and GHI is the global horizontal irradiation which decomposed into diffuse and direct part [18]. There are commercial software products such as PVSYST, PV*Sol, Helioscope, and PV Watts asses the PV system's performance using the VF approach, while RADIANCE and COMSOL software are used for RT approach [25], [32]-[34].

\section{ON-GRID SYSTEM}

PV on-grid system contains PV module, inverters, grid connections, and user loads. This grid has no battery storage in which the generated energy returns back to the main grid. In this paper, the PV system is modeled using the PVsyst software and it is shown in Figure 5. In Figure 5, the components of the system are chosen depending on the bases of their parameter and characteristics. The inverter has two main tasks: first is to load the PV module in order to harvest the most energy and second is to invert the direct current to sinusoidal current to inject it into the grid. Also, Figure 5 illustrates the connection of the PV system and how the loads gain the power from the PV panels [35]. 


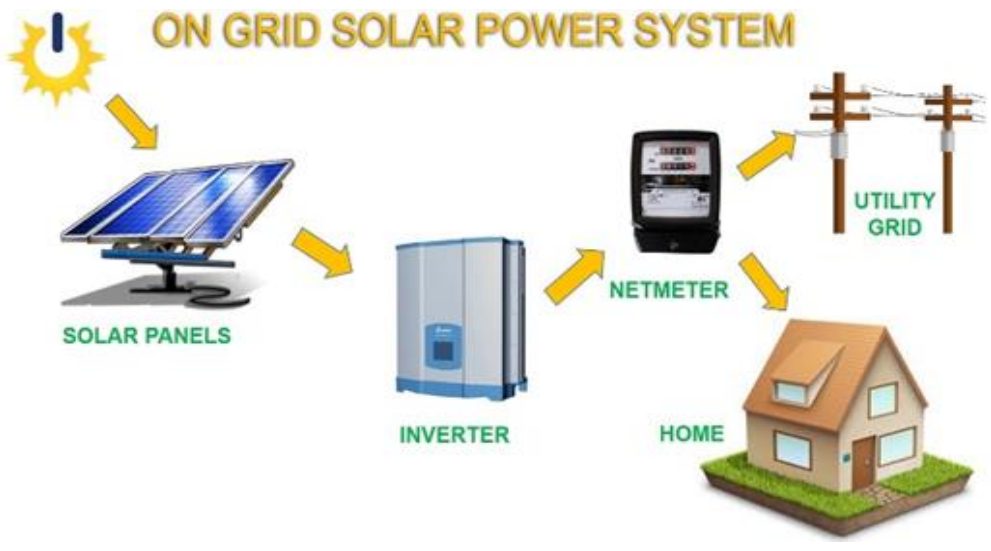

Figure 5. Block diagram of the on-grid PV system

\section{ON-GRID PV SYSTEM SIMULATION AND RESULTS}

As the geographical location of the PV system is essential parameter to produce the maximum energy especially for grid connected configuration, three different locations in Iraq are chosen, the first location is in Al-Mosul city $\left(36.3765^{\circ} \mathrm{N}, 43.1440^{\circ} \mathrm{E}\right)$, the second is in Baghdad city $\left(33.2794^{\circ} \mathrm{N}\right.$, $\left.44.3781^{\circ} \mathrm{E}\right)$ while the third location is in Al-Basrah city $\left(30.448^{\circ} \mathrm{N}, 47.445640^{\circ} \mathrm{E}\right)$. The PV system energy production was simulated using PVsyst 6.8 software. In order to specify suitable location for on grid system using either traditional mono or bifacial PV panel, a comparison of the annual energy production has been simulated at each of the three locations.

The PV array consists of 221 panels (17 series and 13 parallel connected) to obtain $100 \mathrm{kWp}$ nominal power from the array at STC. Two inverters have been used to withstand the power conversion process from dc to ac. The specifications of the system elements are given in Table 2. The effect of different parameters such as albedo, array elevation, tilt angle, and pitch have been studied on the system when using the conventional mono PV panel as well as bifacial PV panel.

Table 2. PV system element specifications

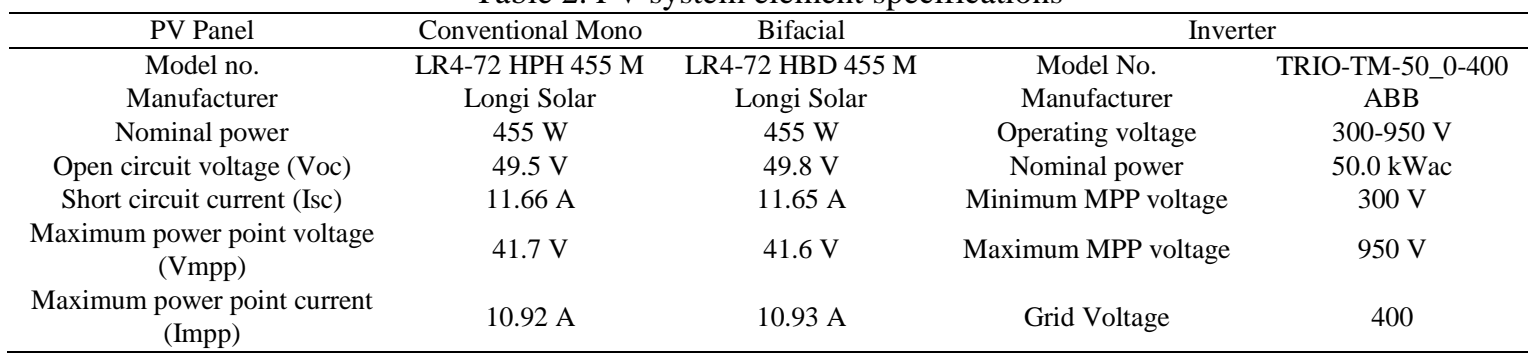

\subsection{Albedo effect}

The albedo is an essential factor that affects the energy production. Figure 6 shows a comparison between the mono and bifacial array yearly energy production for the three location as the albedo is changed. The tilt angle of the panels to produce a maximum output is changed as the albedo changed. For the conventional mono shown in Figure 6(a), 6(c), and 6(e), the tilt angle for maximum energy production has a limited range for different albedo value. For bifacial configuration shown in Figure 6(b), 6(d), and 6(f), the range of tilt angle for maximum energy production is higher than that for the conventional mono. This can be distinguished from Figure 6 as the energy produced as a function of tilt angle for conventional mono, which is sharper than the bifacial for the same value of albedo.

Figure 7(a) and 7(b) show the maximum energy production and tilt angle as a function of albedo for the conventional mono and bifacial array, respectively. It shows that the location of Mosul generates more power for both of the configurations followed by Baghdad, then Basrah. This is due to the temperature difference which is higher in Basrah despite of its higher irradiation value. Table 3 shows the monthly temperature distribution and irradiation for the three location when albedo is 0.4 . It is clear from the collected data for monthly temperature that Basrah has the highest level of temperature overall the year and this will reduce the energy yield of the PV system for both PV configurations. 
When using the bifacial configuration, the tilt angle of the array to produce the maximum energy is higher than the conventional configuration, particularly for high albedo values (0.6-0.8). This will improve the performance of the array as accumulated dust and other dirt are less. Figure 8 represents the bifacial configuration gain over the conventional. Although the bifacial gain for Basrah is higher followed by Baghdad and then Mosul for high albedo (0.6-0.8), it is still more effective to use the bifacial configuration at Mosul location rather than other locations especially for low albedo values (0.2-0.6) as the temperature is lower.

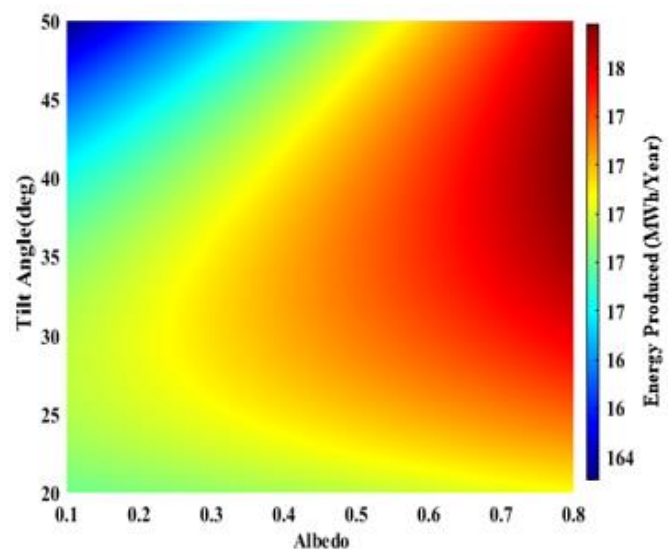

(a)

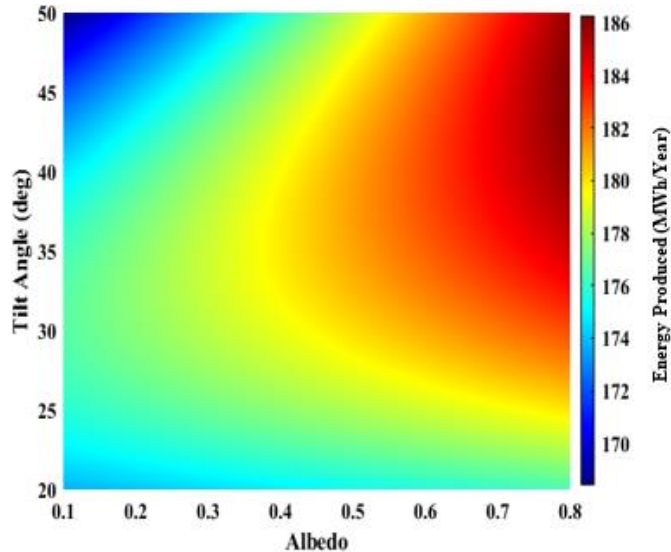

(c)

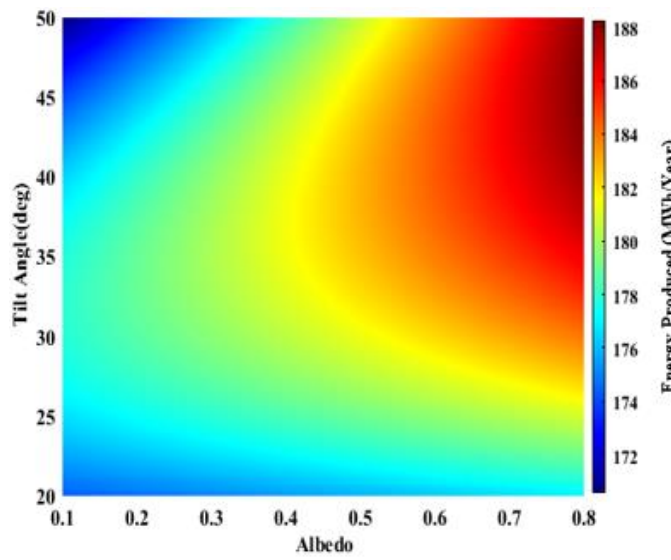

(e)

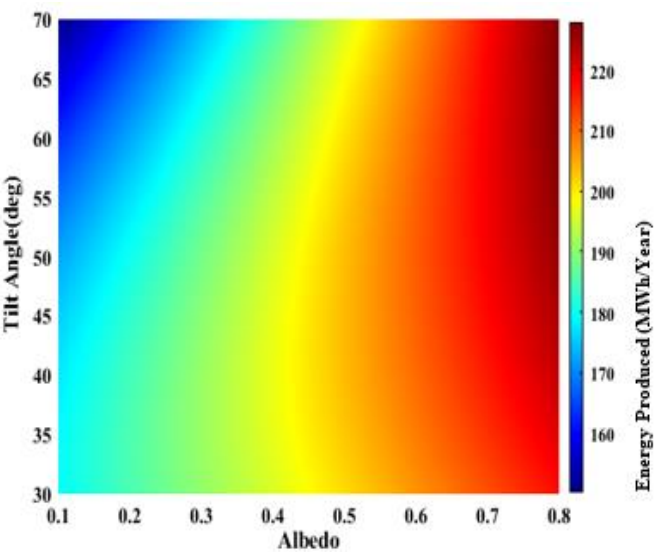

(b)

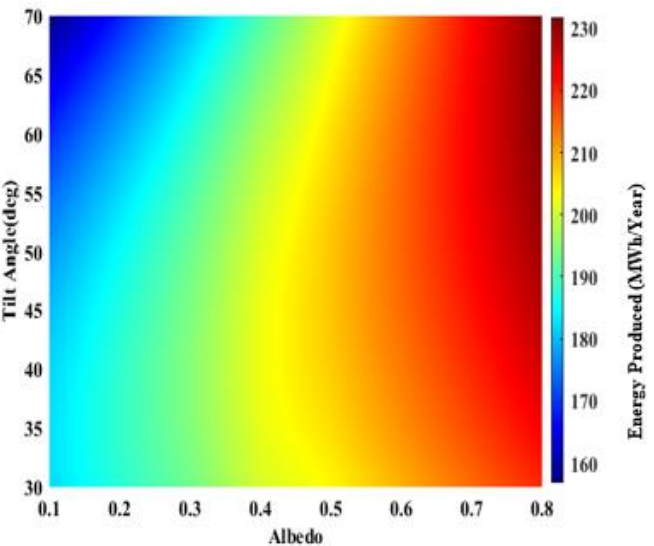

(d)

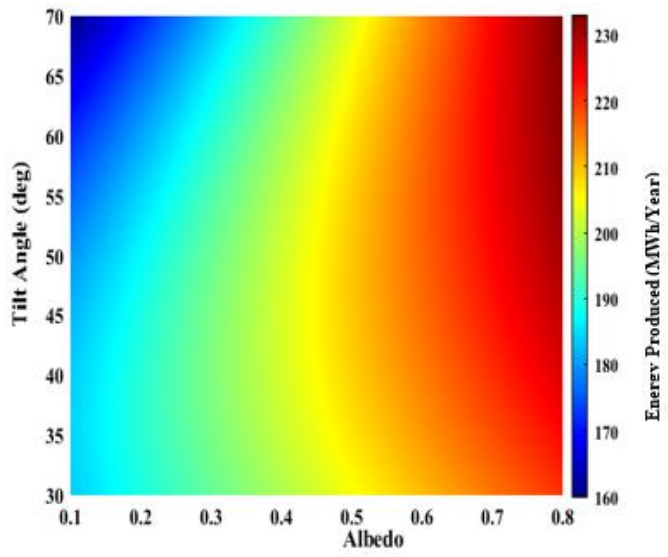

(f)

Figure 6. Mono and bifacial PV array configurations yearly energy production for different albedos and tilt angles; (a) Basrah (mono), (b) Basrah (bifacial), (c) Baghdad (mono), (d) Baghdad (bifacial),

(e) Mosul (mono), and (f) Mosul (bifacial) 


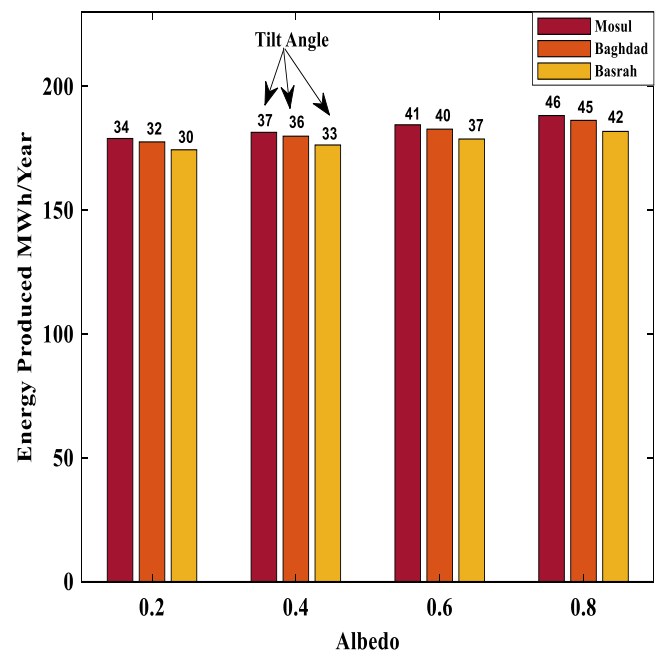

(a)

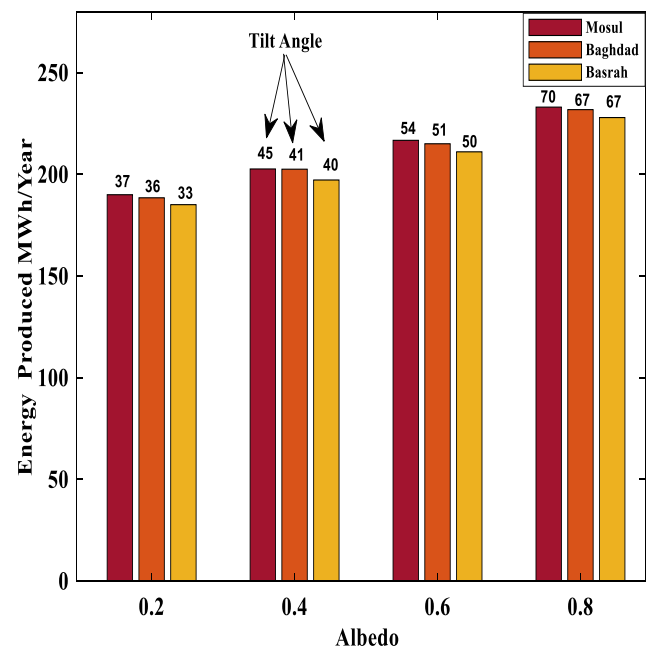

(b)

Figure 7. Maximum yearly energy production for different albedo values; (a) conventional mono configuration, (b) bifacial configuration

Table 3. Temperature and irradiation monthly distribution for the three locations

\begin{tabular}{|c|c|c|c|c|c|c|c|c|c|}
\hline \multirow[b]{2}{*}{ Month } & \multicolumn{3}{|c|}{ Mosul } & \multicolumn{3}{|c|}{ Baghdad } & \multicolumn{3}{|c|}{ Basrah } \\
\hline & $\begin{array}{l}\text { GlobHor } \\
\mathrm{kWh} / \mathrm{m}^{2}\end{array}$ & $\begin{array}{l}\text { DiffHor } \\
\mathrm{kWh} / \mathrm{m}^{2}\end{array}$ & ${ }_{-}^{T_{0} \mathrm{Amb}}$ & $\begin{array}{l}\text { GlobHor } \\
\mathrm{kWh} / \mathrm{m}^{2}\end{array}$ & $\begin{array}{l}\text { DiffHor } \\
\mathrm{kWh} / \mathrm{m}^{2}\end{array}$ & $\begin{array}{c}\mathrm{T}_{-} \mathrm{Amb} \\
{ }^{\circ} \mathrm{C}\end{array}$ & $\begin{array}{l}\text { GlobHor } \\
\mathrm{kWh} / \mathrm{m}^{2}\end{array}$ & $\begin{array}{l}\text { DiffHor } \\
\mathrm{kWh} / \mathrm{m}^{2}\end{array}$ & $\begin{array}{c}\mathrm{T}_{-} \mathrm{Amb} \\
{ }^{\circ} \mathrm{C}\end{array}$ \\
\hline January & 76.9 & 26.97 & 3.35 & 91.8 & 28.52 & 9.77 & 98.6 & 32.24 & 11.93 \\
\hline February & 93.8 & 31.36 & 4.50 & 112.8 & 30.80 & 11.53 & 115.6 & 34.72 & 13.85 \\
\hline March & 141.4 & 45.88 & 9.02 & 154.4 & 46.19 & 16.22 & 150.7 & 51.46 & 18.31 \\
\hline April & 165.6 & 57.00 & 15.80 & 161.7 & 60.60 & 23.06 & 165.3 & 61.80 & 24.96 \\
\hline May & 205.5 & 64.17 & 21.97 & 200.9 & 66.96 & 29.10 & 201.5 & 66.96 & 30.95 \\
\hline June & 230.4 & 57.30 & 27.52 & 226.8 & 58.80 & 33.38 & 227.1 & 57.90 & 34.67 \\
\hline July & 228.2 & 59.21 & 31.14 & 217.0 & 63.86 & 36.15 & 222.6 & 62.00 & 36.56 \\
\hline August & 210.2 & 50.84 & 30.20 & 208.0 & 53.63 & 35.79 & 204.3 & 57.35 & 36.13 \\
\hline September & 165.0 & 42.30 & 25.85 & 166.5 & 45.60 & 32.03 & 170.1 & 48.00 & 32.34 \\
\hline October & 117.8 & 37.82 & 19.60 & 123.4 & 41.23 & 26.24 & 127.4 & 44.64 & 27.02 \\
\hline November & 84.0 & 27.30 & 11.27 & 89.4 & 31.20 & 17.88 & 91.2 & 35.40 & 19.60 \\
\hline December & 68.5 & 24.49 & 5.24 & 81.2 & 27.28 & 11.56 & 84.6 & 31.31 & 13.94 \\
\hline Year & 1787.2 & 524.64 & 17.19 & 1833.9 & 554.67 & 23.63 & 1859.0 & 583.78 & 25.08 \\
\hline
\end{tabular}

Legends: GlobHor: Horizontal global irradiation, DiffHor: Horizontal diffuse irradiation, and T_Amb: Ambient temperature

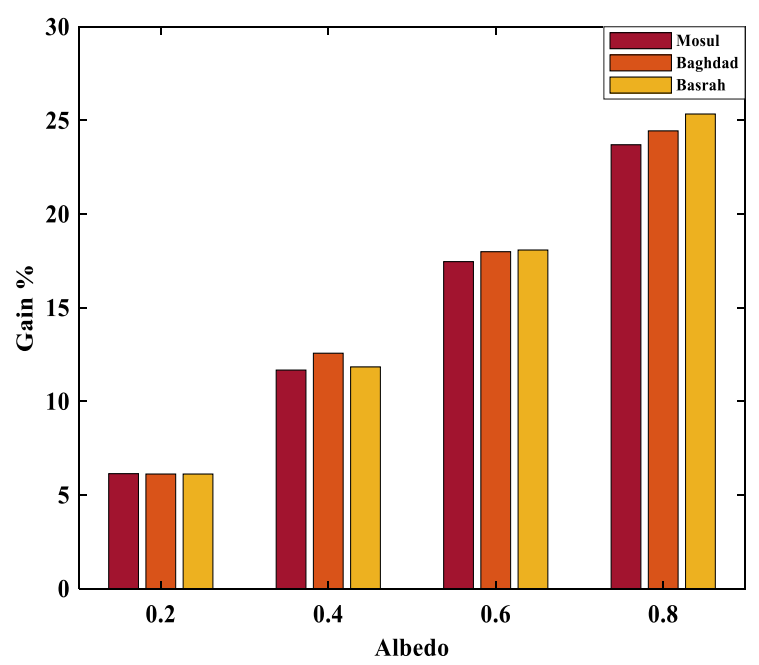

Figure 8. Bifacial gain over conventional mono configuration 


\subsection{Array pitch effect}

To investigate the effect of the array pitch of bifacial configuration on yearly production, the albedo is chosen to be 0.4 and the pitch was changed from $3 \mathrm{~m}$ to $15 \mathrm{~m}$. Figure 9(a) illustrates the yearly production of the three sites for three and five rows. It is obvious that the effect becomes less for pitch greater than $6 \mathrm{~m}$. It is also clear that as the number of rows rises, the production declines. Figure 9(b) shows that the gain of three rows of bifacial configuration is related to the conventional configuration. The gain acquired at Basrah site has the greatest value regardless of the PV array pitch.

\subsection{Array elevation effect}

The elevation of bifacial arrays has been changed from zero to three meters above ground with an albedo of 0.4. Figure 10(a) shows the effect of elevation for the three locations fades away as the elevation becomes more than $1.5 \mathrm{~m}$. Figure 10(b) illustrates the gain obtained from the bifacial array as the elevation changes. It is clear that Basrah site has the greatest gain especially for elevations greater than $1 \mathrm{~m}$.

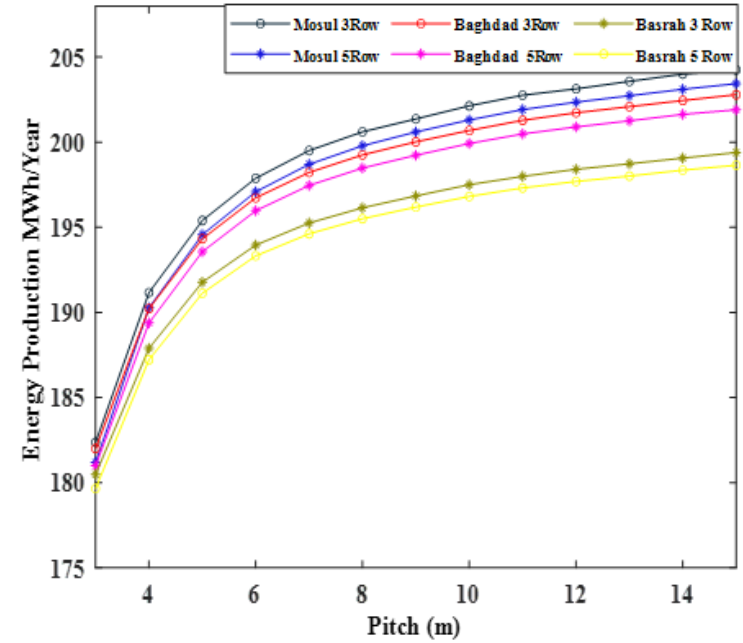

(a)

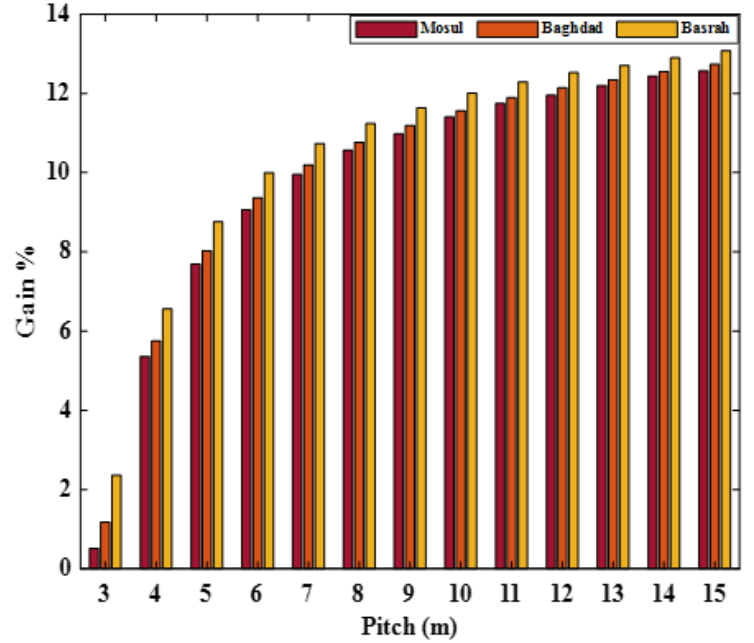

(b)

Figure 9. Effect of bifacial array pitch; (a) yearly energy production for the three locations (3 rows, 5 rows); (b) energy gain of bifacial over conventional mono for 3 rows

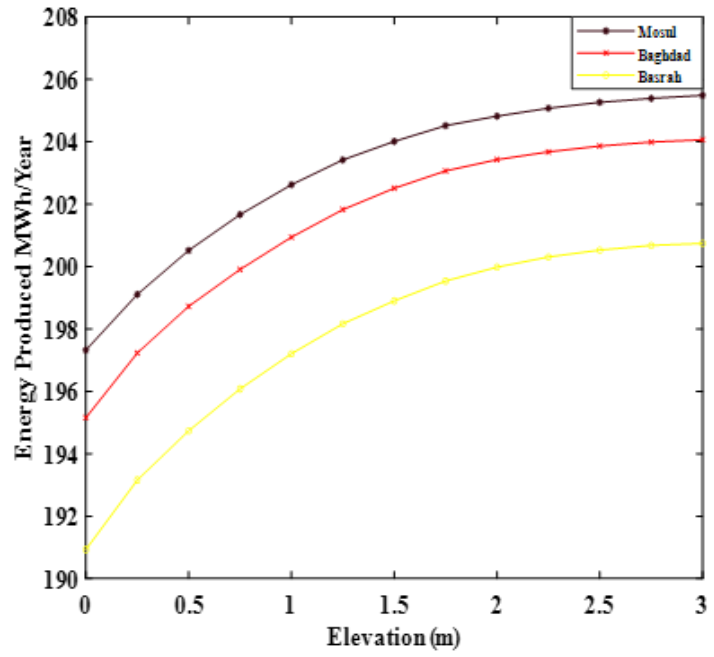

(a)

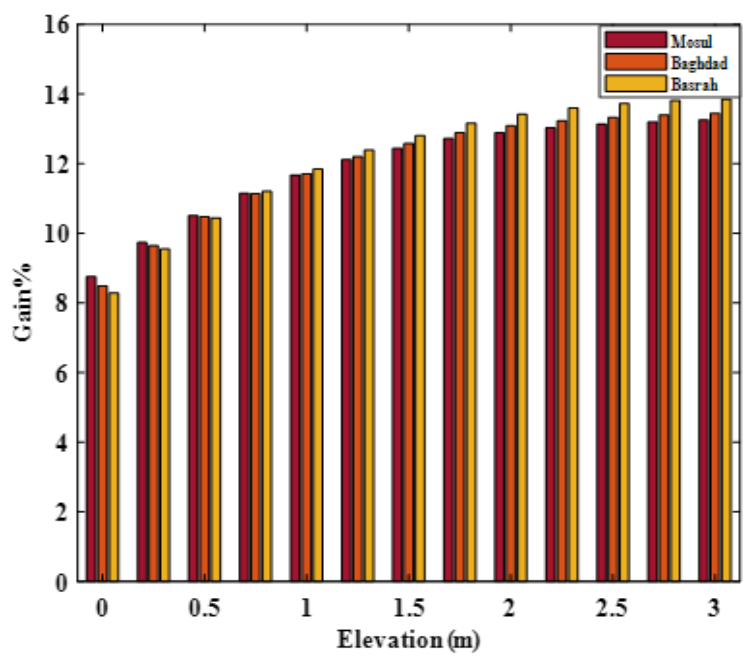

(b)

Figure 10. Effect of array elevation; (a) yearly energy production for the three locations, (b) energy gain of bifacial over conventional mono 


\section{GENERAL CASE PV ARRAY COST COMPARISON}

Through the calculation of the gain obtained from the bifacial over the conventional mono array, a general case is studied for two types of array ( 17 in series, 13 in parallel) at the three sites for albedo 0.4 with bifacial elevation of $1.5 \mathrm{~m}$ above the ground. The cost of the conventional mono array is $\$ 0.218 / \mathrm{Wp}$ while the cost of bifacial is $\$ 0.235 / \mathrm{Wp}$. Table 4 shows a comparison for the energy production gain and cost for the three sites. The PV system which depends on bifacial array has higher cost than the system that depends on the conventional mono array. However, this increasing cost is not the point that decides which system is more economical. The production of the bifacial is more than the conventional mono array for the three sites and the gain obtained is also higher. Therefore, a comparison between production gain and the percentage increase in PV array cost, which is illustrated in Table 2, shows that using bifacial array is more economical than conventional mono array for the three sites since the percentage production gain is approximately $(11 \%)$ and the percentage cost increase is $(7.23 \%)$.

Table 4. Energy production and cost comparison

\begin{tabular}{ccccccc}
\hline Site & $\begin{array}{c}\text { Energy Production } \\
\text { (MWh/Yr) for } \\
\text { Conventional Mono array }\end{array}$ & $\begin{array}{c}\text { Energy Production } \\
\text { (MWh/Yr) using } \\
\text { Bifacial array }\end{array}$ & Gain \% & $\begin{array}{c}\text { Conventional } \\
\text { Mono array Cost } \\
\text { (USD) }\end{array}$ & $\begin{array}{c}\text { Bifacial } \\
\text { array cost } \\
\text { (USD) }\end{array}$ & $\begin{array}{c}\text { Percentage Increase } \\
\text { of Bifacial cost over } \\
\text { Mono Array } \%\end{array}$ \\
\hline Mosul & 181.4 & 204 & 11.0 & $21,920.99$ & $23,630.425$ & 7.23 \\
\hline
\end{tabular}

\section{CONCLUSION}

Choosing the appropriate location for installing a photovoltaic system on the grid is an important factor that affects the energy production of the PV system. Thus, three sites have been chosen in Iraq, Mosul (36.3765 degrees north, 43.1440 degrees east), Baghdad (33.2794 degrees north, 44.3781 degrees east), and Basrah (30.448 degrees north, 47.445640 degrees east) in order to study which of these sites is the best location for installing a PV system. Two types of PV panels have been selected (bifacial and mono) and a comparison between the production of the bifacial array and the production of the conventional mono array for the three sites have been illustrated and discussed. An array of 17 in series and 13 in parallel have been selected to produce $100 \mathrm{~kW}$ for the on-grid PV system. The site of Mosul, despite the low level of radiation in it, the photovoltaic system produces more energy than in Baghdad, which is about $1.5(\mathrm{MWh} / \mathrm{Yr})$ and about $5.1(\mathrm{MWh} / \mathrm{Yr})$ more than in Basrah for both types of panels. This is because the average temperature in the city of Mosul is lower than that in Baghdad and Basrah.

Bifacial array production is affected by different factors such as albedo, elevation and pitch. For albedo of $0.6-0.8$, the array tilt angle was greater for bifacial than that for conventional mono configuration. This will improve the performance of the array as accumulated dust and other dirt are less. The general case study for on-grid PV system shows that the increase in cost for bifacial array was $7.23 \%$ while the increasing in the energy gain has been $11 \%$ as compared to the monofacial array.

\section{REFERENCES}

[1] A. Cuevas, A. Luque, J. Eguren, and J. del Alamo, "50 percent more output power from an albedo-collecting flat panel using bifacial solar cells," Solar Energy, vol. 29, no. 5, pp. 419-420, 1982, doi: 10.1016/0038-092X(82)90078-0.

[2] C. E. Valdivia et al., "Bifacial photovoltaic module energy yield calculation and analysis," 2017 IEEE 44th Photovoltaic Specialist Conference (PVSC), 2017, pp. 1094-1099, doi: 10.1109/PVSC.2017.8366206.

[3] X. Sun, M. R. Khan, C. Deline, and M. A. Alam, "Optimization and performance of bifacial solar modules: a global perspective," Applied Energy, vol. 212, pp. 1601-1610, 2018, doi: 10.1016/j.apenergy.2017.12.041.

[4] H. Sánchez, C. Meza, S. Dittmann, and R. Gottschalg, "The effect of clearance height, albedo, tilt and azimuth angle in bifacial PV energy estimation using different existing algorithms," Proceeding of the III Ibero-American Conference on Smart Cities (ICSC), 2020, pp 315-331.

[5] Lei Chen, J. Cai, C. Wang, M. Rouholamini, and S. Alyami, "Optimal mounting configuration of fixed bifacial PV Systems," 2019 North American Power Symposium (NAPS), 2019, pp. 1-6, doi: 10.1109/NAPS46351.2019.9000339.

[6] T. C. R. Russell, R. Saive, A. Augusto, S. G. Bowden, and H. A. Atwater, "the influence of spectral albedo on bifacial solar cells: a theoretical and experimental study," IEEE Journal of Photovoltaics, vol. 7, no. 6, pp. 1611-1618, 2017, doi: 10.1109/JPHOTOV.2017.2756068.

[7] H. Park, S. Chang, S. Park, and W. K. Kim, "Outdoor performance test of bifacial n-type silicon photovoltaic modules," Sustainability, vol. 11, no. 22, 2019, Art. no. 6234, doi: 10.3390/su11226234.

[8] Z. Syafiqah, M. I. Yusoff, N. A. M. Amin, M. Irwanto, L. W. Zhe, and A. R. Amelia, "Thermal and electrical study for pv panel with cooling," Indonesian Journal of Electrical Engineering and Computer Science (IJEECS), vol. 7, no. 2, pp. 492-499, 2017, doi: 10.11591/ijeecs.v7.i2.pp492-499.

[9] M. Ruzaimi, S. Shafie, W. Z. W. Hasan, N. Azis, M. E. Ya'acob, and E. Elianddy, "Temperature distribution analysis of monocrystalline photovoltaic panel for photovoltaic-thermoelectric generator (PV-TEG) hybrid application," Indonesian Journal of Electrical Engineering and Computer Science (IJEECS), vol. 17, no. 2, pp. 858-867, 2020, doi: 10.11591/ijeecs.v17.i2.pp858867 . 
[10] A. H. Salloom, O. A. Abdulrazzaq, and B. H. Ismail, “Assessment of the performance of bifacial solar panels," International Journal of Engineering and Technical Research (IJETR), vol. 8, no. 7, pp. 2454-4698, 2018.

[11] A. L Mahmood, A. M. Shakir, and B. A. Numan, "Design and performance analysis of stand-alone PV system at Al-Nahrain University, Baghdad, Iraq," International Journal of Power Electronics and Drive System (IJPEDS), vol. 11, no. 2, pp. 921-930, 2020, doi: 10.11591/ijpeds.v11.i2.pp921-930.

[12] S. M. Sami and A. L. Mahmood, "Design and simulation of stand-alone photovoltaic system supplying BTS in Iraq," International Journal of Power Electronics and Drive System (IJPEDS), vol. 12, no. 1, pp. 463-473, 2021, doi: 10.11591/ijpeds.v12.i1.pp463-473.

[13] A. L. Mahmood, "Design and simulation of stand-alone PV system for electronic and communications engineering department laboratories in Al-Nahrain University," EAI Endorsed Transactions on Energy Web, vol. 6, no. 21, 2019, doi: 10.4108/eai.13-72018.156438 .

[14] A. Al-Abass M. Jassem, M. C. Mahdi, and J. Sadiq, "Design and analysis on-grid photovoltaic system for Najaf Province-Iraq," ARPN Journal of Engineering and Applied Sciences (ARPN-JEAS), vol. 15, no. 14, pp. 1530-1535, 2020.

[15] C. Reise et al., "From bifaciality to yield: different bifacial cell technologies may differ even more in annual outdoor performance," Proceeding of 35th European PV Solar Energy Conference and Exhibition (EU PVSEC), 2018, pp. 1252-1255.

[16] G. M. Wilson et al., "The 2020 photovoltaic technologies roadmap," Journal of Physics D: Applied Physics, vol. 53, no. 49, 2020, Art. no. 493001, doi: 10.1088/1361-6463/ab9c6a.

[17] M. T. Patel, R. A. Vijayan, R. Asadpour, M. Varadharajaperumal, M. R. Khan, and M. A. Alam, "Temperature dependent energy gain of bifacial PV Farms: a global perspective," Applied Energy, vol. 276, 2020, Art. no. 115405, doi: 10.1016/j.apenergy.2020.115405.

[18] I. Shoukry, J. Libal, R. Kopecek, E. Wefringhaus, and J. Werner, "Modelling of bifacial gain for stand-alone and in-field installed bifacial PV modulus," Energy Procdia, vol. 92, pp. 600-608, 2016, doi: 10.1016/j.egypro.2016.07.025.

[19] M. Chiodetti et al., "PV bifacial yield simulation with a variable albedo model," Proceedings of the EU PVSEC, 2016, pp.14491456, doi: 10.4229/EUPVSEC20162016-5DP.1.4.

[20] Y. Kotak, M. S. Gul, T. Muneer, and S. M. Ivanova, "Investigating the impact of ground albedo on the performance of PV systems," CIBSE Technical Symposium conference, London/ UK, 2015.

[21] S. Akhlaghi, H. Sangrody, M. Sarailoo, and M. Rezaeiahari, "Efficient operation of residential solar panels with determination of the optimal tilt angle and optimal intervals based on forecasting model," IET Renewable Power Generation, vol. 11, no. 10, pp. 1261-1267, 2017, doi: 10.1049/iet-rpg.2016.1033

[22] S. A. Kalogirou, "Solar thermal systems: components and applications-introduction," Comprehensive Renewable Energy, vol. 3, pp. 1-25, 2012, doi: 10.1016/B978-0-08-087872-0.00301-2.

[23] "Bifacial design guide," LG Electronics Inc., 2017.

[24] C. Deline, A. P. Silvana, F. M., William, R. S. William, and S. S. Joshua, "Understanding bifacial photovoltaics potential: field performance," National Renewable Energy Laboratory NREL, 2019.

[25] C. Hansen et al., "Analysis of irradiance models for bifacial PV modules," 2016 IEEE 43rd Photovoltaic Specialists Conference (PVSC), 2016, pp. 138-143, doi: 10.1109/PVSC.2016.7749564.

[26] I. Pierre, O. Guisan, and R. Perez, "Ground-reflected radiation and albedo," Solar Energy, vol. 44, no. 4, pp. 207-214, 1990, doi: 10.1016/0038-092X(90)90149-7.

[27] R. Perez, P. Ineichen, R. Seals, J. Michalsky, and R. Stewart, "Modeling daylight availability and irradiance components from direct and global irradiances," Solar Energy, vol. 44, no. 5, pp. 271-289, 1990, doi: 10.1016/0038-092X(90)90055-H

[28] B. Wittmer, "Simulating bifacial fixed tilt and tracking systems with PVsyst," PV Magazine Webinar, 2019.

[29] Y. Ufuk et al., "Analysis of the annual performance of bifacial modules and optimization methods," IEEE Journal of Photovoltaics, vol. 5, no. 1, pp. 320-328, 2015, doi: 10.1109/JPHOTOV.2014.2364406.

[30] D. Berrian and J. Libal, "A comparison of ray tracing and view factor simulations of locally resolved rear irradiance with the experimental values," Progress in Photovoltaics: Research and Applications, vol. 28, no. 6, pp. 609-620, 2020, doi: 10.1002/pip.3261.

[31] Y. Ufuk et al., "Simulation of energy production by bifacial modules with revision of ground reflection," Energy Procedia, vol. 55, pp. 389-395, 2014, doi: 10.1016/j.egypro.2014.08.111.

[32] A. Asgharzadeh et al., "A benchmark and validation of bifacial PV irradiance models," 2019 IEEE 46th Photovoltaic Specialists Conference (PVSC), 2019, pp. 3281-3287, doi: 10.1109/PVSC40753.2019.8981272.

[33] A. Grover, K. Anita, and J. Dheeraj, "Design and simulation of $20 \mathrm{MW}$ photovoltaic power plant using PVSyst," Indonesian Journal of Electrical Engineering and Computer Science, vol. 19, no. 1, pp. 58-65, 2020.

[34] A. Shishavan, "Bifacial photovoltaic (PV) system performance modeling utilizing ray tracing," Ph.D. thesis, University of Iowa, 2019.

[35] K. Matiyali and A. Ashok, "Performance evaluation of grid connected solar PV power plant," 2016 2nd International Conference on Advances in Computing, Communication, \& Automation (ICACCA) (Fall), 2016, pp. 1-5, doi: 10.1109/ICACCAF.2016.7748989.

\section{BIOGRAPHIES OF AUTHORS}

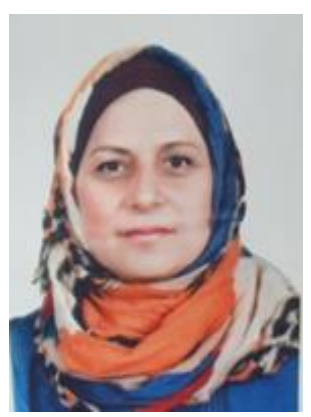

Amina Mahmoud Shakir (iD S SC P received the B.Sc. Degree in Electrical Engineering from the University of Technology/Baghdad, Iraq in 1990. Her M.Sc. in power and machinery engineering from the University of Technology/Baghdad, Iraq in 1998. Her Ph.D. in power system from Baghdad university in 2007. She is currently an instructor at Al Nahrain University/Electronic and the communications Engineering Department. Her research includes photovoltaic modeling and control, energy conversion from renewable sources and power electronics. She can be contacted at email: aminaalkafajiam@gmail.com. 


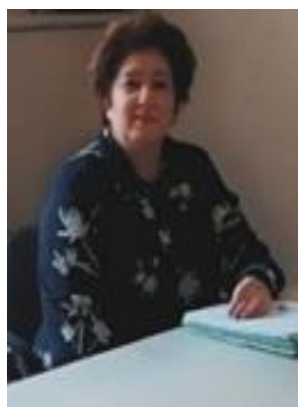

Siba Monther Yousif (D) SC P received B.Sc. degree in Electronic and Communications Engineering and M.Sc. degree in Electronics Engineering from the University of Technology, Iraq, in 1992 and 2007, respectively. She received Ph.D. degree in Electronics Engineering from the Universiti Putra Malaysia, Malaysia, in 2016. She has 12 years of experience in designing and developing electronic circuits. She joined the staff of the Department of Electronic and Communications Engineering at Al-Nahrain University, Baghdad, Iraq, since 2007. She can be contacted at email: dr.sibamonther@gmail.com.

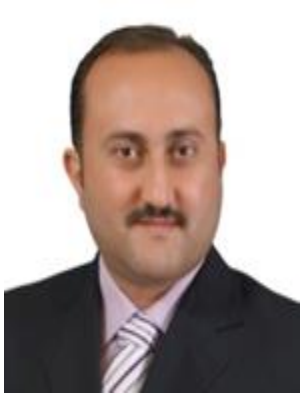

Anas Lateef Mahmood (D) $8 \mathrm{~S}$ SC P received his B.Sc., M.Sc., and Ph.D. in Electronic and Communications Engineering/Electronic Circuits and Systems from Al-Nahrain University college of engineering in 1999, 2002, and 2007 respectively. He is currently the head of Electronic and Communications Department. His research interest includes power electronics and renewable energy. He can be contacted at email: anas.lateef.1@ ced.nahrainuniv.edu.iq. 